certificates were not negotiable. The fluidity of share certificates within the brokerage system depends not upon negotiability, but upon confidence between brokers. It is at the point where a certificate enters brokerage or banking channels that negotiability has its greatest significance. Negotiability at that point serves to protect careless brokers and bankers who introduce certificates into the brokerage system without confirming the registered owner's authorization to transfer the shares. This protection is at the expense of private investors, who as a class, cannot protect themselves with the ease or effectiveness that brokers can.

\title{
THE TRUST INDENTURE ACT OF 1939: LIMITATIONS ON THE TRUSTEE'S PRIVILEGE OF LENDING TO THE OBLIGOR
}

Most trust companies which serve as trustees for indenture security issues are also commercial bankers making short-term loans. ${ }^{x}$ It may happen, therefore, that such companies will occupy the dual position of indenture trustee and creditor of the obligor on the indenture securities. As trustee, the trust company's duty to the bondholders requires that it refrain from any action which may diminish the value of the property available to the indenture security holders to satisfy the indenture lien or claim; as a bank creditor, the trust company's duty to its depositors and stockholders compel it, in conformity with sound banking practice, to make itself whole on any outstanding loans to the obligor. Because of the risk that such a trustee-creditor may disregard its fiduciary duties to the investor, the Trust Indenture Act of $1939^{2}$ requires a qualified indenture to contain certain provisions ${ }^{3}$ which protect the indenture security holder against the trustee's improving its position as creditor within four months of default on the indenture obligation. ${ }^{4}$

Prior to the Trust Indenture Act, there were but few suits to compel a corporate trustee to share with investors any preferential payments which were made by the obligor on debts to the trustee and which were received by the

\footnotetext{
- For example, see SEC, Report on the Study and Investigation of the Work, Activities, Personnel and Functions of Protective and Reorganization Committees, pt. VI, Trustees under Indentures, at 99 (1936). Of 308 corporate trustees, the commission found 240 were also commercial bankers.
}

${ }_{53}$ Stat. II49 (r939), I5 U.S.C.A. \& 77 aaa (Supp. I939).

3 The commission will refuse to allow a registration statement for the sale of indenture securities to become effective if the indenture does not contain the provisions required by Sections 3 Io to 3 I 8 inclusive, $\S_{305}(\mathrm{~b})(2)$. Section references are to the Trust Indenture Act of r939, which is title III of the Securities Act of r933.

4\$§ $3^{I I}, 3^{\times} 3(a)(2),(3), 3^{I} 3(b)(2)$. A "default," except where the trustee acts as trustee for two or more qualified indentures, is defined as "any failure to make payment in full of principal or interest, when and as the same becomes due and payable" by the terms of the indenture, $\S 3 \operatorname{Ir}(\mathrm{a})$. 
trustee shortly before default on the indenture. ${ }^{5}$ Where recovery was granted, the trustees were required to share the property received pro rata with the security holders. ${ }^{6}$ Recovery in these few cases, however, seems to have been limited to those situations where it was shown that the trustee either knew the obligor was insolvent, 7 had defaulted, ${ }^{8}$ or permitted the violation of a "negative pledge"' or substitution clause. ${ }^{\text {To }}$ The difficulty confronting the security holders in getting judgment is apparent. They usually lack any information that the trustee has made loans to the obligor or has protected itself as creditor before default. Even if the security holders have this information, however, they still have the burden of proving that the trustee in making a secured loan or in bettering its position knew that the obligor was insolvent or had defaulted or was violating a negative pledge or substitution clause. ${ }^{\text {xx }}$

\section{I}

The investor in indenture securities qualified under the act will be better in$\checkmark$ formed of the trustee's lending to the obligor. In this respect, a qualified indenture must require that the trustee submit, at least annually, reports of any un-

$s$ Conover v. Guarantee Trust Co., 88 N.J. Eq. 450, 102 Atl. 844 (I917); Chase Nat'l Bank of City of New York v. Sweezy, 28I N.Y. Supp. 487 (S.Ct. 193I); Kaplan v. Chase Nat'l Bank of City of New York, I 56 Misc. 47r, 28I N.Y. Supp. 825 (S.Ct. I934); Drueding v. Tradesmens Nat'l Bank \& Trust Co., 3I9 Pa. I44, I79 Atl. 229 ( City of New York, N.Y.L.J. 77I-2, Sept. 2I, I936 (N.Y. S. Ct.), noted in 4 Univ. Chi. L. Rev. 346 (1937); cf. Hazzard v. Chase Nat'l Bank of City of New York, 159 Misc. 57, 287 N.Y. Supp. 54I (S. Ct. I936).

'Kaplan v. Chase Nat'l Bank of City of New York, I56 Misc. 47ז, 28I N.Y. Supp. 825 (S. Ct. I934); Starr v. Chase Nat'l Bank of City of New York, N.Y.L.J. 77I-2, Sept. 2I, 1936 (N.Y.S. Ct.).

7 See Drueding v. Tradesmens Nat'l Bank \& Trust Co., 3r9 Pa. I44, I79 Atl. 229 (I935).

${ }^{8}$ Starr v. Chase Nat'l Bank of City of New York, N.Y.L.J. 771-2, Sept. 2r, I936 (N.Y. S. Ct.).

9 Kaplan v. Chase Nat'l Bank of City of New York, 156 Misc. 47I, 28I N.Y. Supp. 825 (S. Ct. I934); see Kelly v. Central Hanover Bank \& Trust Co., II F. Supp. 497, 509 (N.Y. r935).

For discussion of negative pledge clauses, see Jacob, The Effect of Provision for Ratable Protection of Debenture Holders in Case of Subsequent Mortgage, 52 Harv. L. Rev. 77 ( 1938 ); Protection for Debenture Holders, 46 Yale L. J. 97 (r936).

${ }^{\text {xo }}$ See Richardson v. Union Mortgage Co., 210 Iowa 346, 228 N.W. ro3 (r929); Hazzard v. Chase Nat'l Bank of City of New York, I59 Misc. 57, 287 N.Y. Supp. 54I (S. Ct. I936).

${ }^{3 I}$ See Chase Nat'l Bank of City of New York v. Sweezy, 28I N.Y. Supp. 487 (S. Ct. r93I) (where it was held that transferring of securities purchased with proceeds of loan was intended as a purchase money mortgage, which is an exception to the negative pledge clause); Hazzard v. Chase Nat'l Bank of City of New York, I59 Misc. 57, 287 N.Y. Supp. 54I (S. Ct. 1936) (where although the trustee negligently permitted a substitution of assests relief was denied because of exculpatory clause releasing the trustee from liability for all acts except those done in willful default or in gross negligence. The Trust Indenture Act prohibits exculpatory clauses which release the trustee from liability for its "own negligent action, its own negligent failure to act, or its own willful misconduct $\ldots . ., " \S_{355}(\mathrm{~d})$ ). 
paid advances-totaling more than one-half of one per cent of the outstanding principal obligation - which it has made as trustee and for the reimbursement of which it may or does claim a prior lien on the trust property. ${ }^{\mathrm{x}}$ In addition, if such unpaid advances total more than ten per cent of the outstanding principal, then, as to further advances of this type, interim reports will be necessary. ${ }^{13}$ With reference to these provisions of the act, it should be observed that the courts, in a few cases before the act, held that a trustee who failed to notify the bondholders of advances for which it claims priority over the indenture lien, will be denied priority. ${ }^{14}$ Under the act a qualified indenture will, in addition to the information concerning advances made in its trustee capacity, require that the trustee's report convey such more important information as "the amount, interest rate, maturing date of all other indebtedness owing to it in its individual capacity," with a brief description of the collateral.15 The ordinary loans to the obligor made by the trustee as a commercial bank will fall into this class. For this type of notice requirement there appears to be no common law precedent.

The provisions dealing with reports of the trustee-creditor relationship are supplemented by those requiring notice of substitution and release of property held under the indenture and those requiring that the obligor furnish to the trustee opinions of an expert that the substitution or release will not impair the value of the property under the indenture. ${ }^{16}$ These provisions were meant to protect the indenture security holders against a substitution or release which will result in a reduction in value of the assets securing their claims. Concern may be expressed, however, over the adequacy of protection given by such notice of releases and substitutions in view of the fact that it is not necessary that the obligor furnish independent opinions until the releases in any year amount to ten per cent of the outstanding principal, and then only as to such releases in which the property involved has a fairvalue in excess of $\$ 25,000$ or one per cent of the outstanding principal. ${ }^{17}$

II

Besides those provisions which relate to the disclosing of the status of the trustee as a creditor, a qualified indenture will contain clauses providing for the relief to be obtained by the investor from the trustee who improves its creditor

${ }^{x 2} \S 3{ }^{13}(a)(2)$.

${ }^{23}$ This report must be given within ninety days of occurrence of the advance, $\S 33_{3}(b)(2)$.

${ }^{14}$ Marshall \& Ilsley Bank v. Guaranty Investment Co., 213 Wis. 415, 250 N.W. 862 (I933), noted in 47 Harv. L. Rev. 882 (r934); Wright v. Chandler, I8o Tll. App. 476 (r913). Contra: : First Trust Co. of Lincoln, Neb. v. Ricketts, 75 F. (2d) 309 (C.C.A. 8th I934).

${ }^{25} \delta_{3} \pi_{3}(a)(3)$. ${ }^{26} \delta 3_{3 \times 3}(\mathrm{a})(5), 3^{\mathrm{r}} 3(\mathrm{~b})(\mathrm{x}), 3^{\mathrm{I}} \mathrm{4}(\mathrm{d})(\mathrm{x}),(3)$.

${ }^{77} \S_{3 \mathrm{I}}(\mathrm{d})(\mathrm{r}) . \S_{3 \mathrm{I}}(\mathrm{d})(3)$ also requires an independent opinion as to the fair value of any property other than the original security to be subjected to the lien of the indenture if, (a) the property was used within six months for similar business purposes to those contemplated by the obligor, and (b) the fair value of the property to the obligor is not less than $\$ 25,000$ and not less than one per cent of the principal outstanding. 
position or gives a secured loan to the obligor within four months of default..$^{18}$ The argument for such relief is illustrated by the $H o e^{x 9}$ and $C u b a$ Cane $e^{20}$ case histories compiled by the Securities and Exchange Commission.

In the Hoe case the trustee for the bondholders became a secured shortterm creditor of the obligor in I926. Two years later, as a result of modification in the short-term loan agreement, the collateral ratio for the obligor's debt to the trustee was increased with the privilege in the obligor, however, of withdrawing any excess collateral. On March I7, I932, the same day on which the Hoe directorate voted to default on the bond interest payment falling due April I, I932, the loan agreement was altered so that the Hoe company would not be able to withdraw the excess of $\$ 285,000$ over the required collateral ratio.

In the Cuba Cane case, the trustee for Cuba Cane's debenture issue maturing January I, I930, in co-operation with other banks, had extended seasonal credit to the obligor. In November, I928, with the bottom falling out of the sugar market, the banks required as consideration for any extension of credit that their old loans be secured. As a result, trade acceptances and securities were given as collateral. In June, I929, the trustee and another bank acquired for an independent loan a second lien on this same collateral. During the same month a readjustment was deemed necessary to avoid default on the debenture issue which would mature less than seven months thereafter. After a reorganization which was effected a few months later, the trustee and other banks continued lending money to the new Cuban Cane Products Company. In I930, the banks, including the trustee, obtained a mortgage on Cuban Cane property and assets to secure their claim. Later, in I93I, in order further to secure these loans a wholly owned Cuban Cane subsidiary mortgaged its principal free assets which otherwise would have been available to satisfy the debenture securities. The trustee however, did not resign until December, 1932, eight months after foreclosure proceedings were begun by the banks on the former mortgage.

To lessen the risk of losses to investors as illustrated by the Hoe and Cuba Cane examples, ${ }^{2 x}$ the act requires a qualified indenture to state that the trustee holds in a "special account," to be shared with the security holders, any collateral or payment given the trustee by the obligor within four months of de-

${ }^{8} 83$ II.

29 SEC, op. cit. supra note $\mathrm{I}, \mathrm{pt}$. VI, at $83-8$.

${ }^{20} \mathrm{SEC}$, op. cit. supra note I, pt. VI, at 88-98. Another SEC case history is that of the Frye Investment Co. published in H.R. Hearing on H.R. 2I9I and H.R. 5220, 76th Cong., Ist Sess. 249-5I (1939).

${ }^{21}$ See Comments by the Guaranty Trust Co. of New York on Certain Features of the Report of Securities and Exchange Commission on Trustees under Indentures 39, 70 (I937) where it is maintained the losses suffered by the security holders in the Cuba Cane and Hoe cases were caused by general economic conditions. See also H.R. Hearing on H.R. 2Igr and H.R. 5220, 76th Cong., Ist Sess. 249 (I939) (Mr. Burke of the SEC admits that apparently the manipulations in the Hoe case did not cause any loss to the investors). 
fault.22 Apportionment of this "special account" according to the formula set by the act will ordinarily result in a prorating of the "special account" between the trustee and investors, as was done in a few cases before the act.23 But since the trustee will be automatically accountable for many preferential transfers made to it within the four-month period, the necessary requirements for recovery before the act are somewhat lessened for it no longer will have to be shown that there was a negative pledge or substitution clause violation or that the trustee knew the obligor was insolvent or had defaulted. ${ }^{24}$ It is important to notice, however, that the provisions for relief, required by the act, are the same for all qualified indentures, whether the indenture claim is secured by specific property or is merely a general claim against the obligor. This uniform requirement for all indentures should be compared with the provisions in the original draft ${ }^{25}$ of the act largely prohibiting debenture ${ }^{26}$ trustees from being a creditor of the obligor, or, if such trustees nevertheless lent to the obligor, giving the debenture holders a priority as to any assets these trustees obtained in bettering their creditor position within four months of default. ${ }^{27}$

One of the reasons for these provisions in the original draft is found in another type of incident disclosed in the Cuba Cane history. ${ }^{28}$ In this instance, Cuba Cane had issued debentures in I920 with a negative pledge clause binding it not to mortgage its property except to acquire additional property or to renew existing liens. In order to get credit in I92I from a group of banks, which included the trustee, it became necessary, however, for Cuba Cane to promise that bonds would be issued to pay off the bank loans. Between $\mathrm{xg} 20$ and I922, this promise was fulfilled by the transfer from one wholly owned subsidiary to another of property obtained with the proceeds of the debenture issue. The recipient subsidiary was then able to market a mortgage bond issue in I922 secured by the transferred property. With the proceeds from the sale of these bonds the debenture trustee and other banks were paid on their short-term loans.

Because of strong objection, however, the provisions prohibiting debenture trustee loans were deleted.9 It was argued that to prohibit such trustees from

$22 \S 3 \operatorname{II}(\mathrm{a})$.

${ }^{23} \S 3 \operatorname{Ir}(\mathrm{a})$; cases cited in note 6 supra.

26 "Debenture" is used here to mean a security which is an unsecured credit claim against the obligor.

${ }^{27}$ S. 2344, 75th Cong., Ist Sess. $8 \$ 7(\mathrm{~b})(6), 7(\mathrm{c})$ (r937). Trustees of issues having a maturity period of less than five years were likewise prohibited from lending to the obligor. Probably a reason for this latter prohibition and penalty was that it was felt that, because of the short duration of such securities, any short-term loans by the trustee were in direct competition with the indenture loan.

${ }^{28}$ SEC, op. cit. supra note I, pt. VI, at 98 .

${ }^{29}$ S. Hearing on S. 2344, 75th Cong., Ist Sess, 89, 9I, I19, I30, 133, I58 (1937). The similar provisions as to trustees of issues of less than five years' maturity were also criticized and dropped from the bill. 
lending to the obligor was to deprive trust companies of a needed source of business. ${ }^{30}$ As for the investor, it was said that to penalize a trustee-creditor by requiring it to share "preferences" with the security holders was sufficient protection. ${ }^{3 \mathrm{I}}$ Besides, the critics maintained that the trustee's lending operated to the security holder's benefit since the trustee is more concerned with the welfare of the obligor than is an ordinary bank creditor. ${ }^{32}$

The arguments given for removing the prohibition against debenture trustee loans are not entirely convincing. The Securities and Exchange Commission's finding that but a small portion of trustees were creditors of the obligor casts doubt upon the indispensability of the lending privilege. ${ }^{33}$ Anyway, if the debenture trustee suffers an appreciable loss of business from the denial of the lending privilege, the additional fees such trustee may charge may be justifiable in view of the added protection the investors will receive. ${ }^{34}$ The contention, however, that allowing the trustee to lend to the obligor benefits the investor seems cogent since the trustee may have handled the obligor's banking business for many years and thus be the only bank with an interest in seeing that the obligor will not fail because of default. Nevertheless, in view of the Cuba Cane incident it is doubtful that merely sharing transfers made shortly before default gives a debenture holder sufficient protection.

Although the Trust Indenture Act does not provide for the removal 35 of a trustee on the ground that it is a creditor, the notice requirements ${ }^{36}$ of the act may raise the removal question since the trustee's reports of its status as creditor of the obligor may indicate a conflict of interests. ${ }^{37}$ Perhaps, in a situation where a sufficient conflict is indicated, a court, in its discretion,,$^{8}$ may assert the same power of removal over a corporate trustee as over an ordinary trustee. ${ }^{39}$

${ }^{30}$ Ibid., at 89 .

${ }^{3}$ Ibid., at 9 I.

${ }^{32}$ Wham, Trustees under Indentures, 23 A.B.A.J. ×79, I8I (1937).

${ }_{33} \mathrm{SEC}$, op. cit. supra note 4 , pt. VI, at I23. Of 308 issues investigated, the trustee was a creditor of the obligor within a year of default in nineteen instances. But see Posner, The Trustee and the Trust Indenture: A Further Study, ${ }^{6}$ Yale L.J. 737, 792 (r937).

${ }^{34}$ See Hazzard v. Chase Nat'l Bank of City of New York, 159 Misc. 57, 84, 287 N.Y. Supp. 54I, 57 I (S. Ct. 1936), where it was said: "... . It would be far better for the bondholders to pay a much larger compensation to a trustee, and be able to insist upon the usual vigilance of a fiduciary."

${ }_{35}$ " $P$ robably the most drastic preventive remedy available to the bondholder is removal of the trustee," Posner, op. cit. supra note 33 , at 777.

${ }^{36} \S \S 3^{3} 3(\mathrm{a})(2),(3), 3^{\mathrm{r}} 3(\mathrm{~b})(2)$.

${ }^{37}$ Courts have recognized a conflict of interest in a trustee's being creditor of the obligor. See, for example, Hazzard v. Chase Nat'l Bank of City of New York, I59 Misc. 57, 63, 287 N.X. Supp. 54I, $54^{8}$ (Sup. Ct. 1936).

${ }^{38}$ Conover v. Guarantee Trust Co., 88 N.J. Eq. 450, Io2 Atl. 844 (19I7).

${ }^{39}$ Sargent v. Howe, 2I Ill. $x_{47}$ (1859); White v. Macqueen, 360 Ill. 236, 195 N.E. 832 (1935); see Conover v. Guarantee Trust Co., 88 N.J. Eq. 450, 467, I02 Atl. 844, 85 r (x9r7). Contra: Caldwell v. Hill, I79 Ga. 4I7, I76 S.E. 38I (I934). 
In such a case, any argument that the act by implication prohibits the removal of the trustee is answered by the rule that statutes in derogation of the common law are to be strictly construed.

\section{III}

The extreme caution taken in drafting the "preferential collection" provision of the act has resulted in a complicated formula of apportionment subject to numerous exceptions where no apportionment is required. $4^{\circ}$ The complex sharing of the "special account," required by Section $3 \operatorname{II}(\mathrm{a})$, is to be

in such manner that the trustee and . . . . security holders realize, as a result of payments from such special account and . . . . dividends . . . in bankruptcy or receivership or .... reorganization...., the same percentage of their respective claims, figured . . . . before crediting to the respective claims . . . dividends . . . in bankruptcy or receivership or .... reorganization .... , but after crediting .... receipts on .... their respective claims . . . from all other sources. . . . ${ }^{48}$

In reorganization cases, however, the act permits the court to approve a fair plan which represents only an approximate application of the formula. $4^{2} \mathrm{Al}$ though in most cases the formula will result in a prorating of the "preferences" between the security holders and trustee, instances may arise where because of a mechanical application of the formula there will not be a strict prorating. ${ }^{43}$ Perhaps, to prevent any anomalous results, it may have been more suitable to

$40 \S 3$ II.

4 \& $8 \times 1(a)$

$42 \S 3 \times I(a)$.

43 Suppose the following facts: a) a trustee of a qualified debenture issue of $\$ 1, \infty 00, \infty 00, b)$ the trustee lends the obligor $\$ I, \infty 00, \infty 00$ for which it takes a claim inferior to the debenture claim, c) the trustee must account for a $\$ 400,000$ payment received from the obligor within four months of default on the debenture, $d$ ) in bankruptcy the debenture holders receive $\$ 500$,$\infty \infty$ because of their prior claim, and the trustee receives nothing.

If the rule required by Section $3^{\mathrm{Ir}}$ is strictly applied in this case, the trustee will get all of the special account of $\$ 400,000$, for the rule requires that, in apportioning the proceeds of the special account so that each party will receive as nearly as possible the same percentage of his respective claim, payments received in bankruptcy be credited toward the recipient's percentage. These latter payments, however, do not have to be shared; therefore the final percentages may sometimes be unequal as in the instant case. The effect of such a distribution will be that the priority of the security holders will be partially neutralized.

Nevertheless, it may be possible for a court confronted with the problem of this example to construe this section so that the priority of the investor is preserved. To accomplish this result, the prior claim of the debenture holders could be, for the purpose of this section, a "secured claim" and since "any payment with respect to the secured portion," of the recipient's claim reduces its claim to that extent and is not included in determining the distribution of the "special account," the trustee and security holders will share the "special account" of \$400,$\infty \infty 0$ in the ratio of 2 to $I$. See $\S 3 \operatorname{II}(a)$.

The converse of the above example would be where the trustee has a prior claim as to which the trustee tries to improve his position so that a "special account" is set up. The same diffculty would arise as to the distribution of such a fund. Such a situation, however, is hard to contemplate because many of the creditor relationships, in which the trustee could conceivably have a priority, are exempted from the apportionment rule. 
have framed a general rule to govern the distribution of the "special account." 44 The addition of such a rule, however, might cast doubt on the method of apportionment in a situation where the present specific provisions properly cover the case.

Another problem regarding the "special account" may arise where a guarantor for the obligor pays the security holder's claim. The argument may then be urged that the guarantor be subrogated to the rights of the security holders in the "special account." It seems that if the reason for apportionment is to prevent a loss to the security holders, ${ }^{45}$ such a claim to subrogation should be denied.

It should be observed, however, that an arbitrary operation of the apportionment rule is prevented where the same trustee is trustee under two or more qualified indentures for the same obligor. In such an instance the "special account," required by the provisions of Section 3 II (a), is to be set up for the benefit of all security holders four months before default on any of these indentures, thereby preventing the holders of the issue first defaulting from sharing exclusively with the trustee the funds or property in the "special account." 46

Although the application of the apportioning rule is stated generally, many qualifications limit it considerably.47 The first exception excludes "any .... reduction [of the trustee's claim] resulting from .... the exercise of any right of set-off which the trustee could have exercised if a petition in bankruptcy had been filed by or against such obligor upon the date of such default." ${ }^{8}$ By incorporating this set-off rule, the act extends the bankruptcy rule ${ }^{49}$ that a bank may

44 Such a rule may be: the security holders and trustee are to share the "special account" in proportion to their respective unsecured claims against the obligor, except that in case one of the respective unsecured claims has a priority the "special account" shall be distributed so that the priority is not wholly or partially defeated.

${ }_{45}$ Section 302 states the "Necessity for Regulation." $\quad 4^{6} \S 3 \mathrm{Ir}(\mathrm{a})$.

47 \$II (a), (b). Subsection 3 II (c) amounts to an amendment of the Public Utility Holding Company Act of 1935 . The reason for the change was a case arising under the Holding Company Act, In the Matter of Gulf States Utilities Co., Holding Co. Act Rel. 1446 (1939). In that case the commission so applied the act as to prevent the obligor of bonds from issuing an unsecured note to the trustee of the bond issue as security for a loan by the trustee to the obligor. The commission refused to consent to the giving of the note because if the note were issued to the bond trustee, the trustee would be assuming the conflicting position of creditor of the obligor. It was immediately pointed out that such action by the SEC was equivalent to the prohibition of the trustee's being a creditor of the obligor, a relationship not forbidden a trustee under an indenture qualified under the Trust Indenture Act, H.R. Hearing on H.R. 2Igr and H.R. 5220, 76 th Cong., Ist Sess. 203 (I939). As a result, this last subsection, 3 Ir(c), was added allowing an indenture trustee, though subject to the Holding Company Act, to become a creditor of the obligor by the trustee's acquiring a security or note of the obligor. But the trustee who becomes a creditor in this manner must agree to conform to the requirements set for a trustee-creditor under an indenture qualified under the Trust Indenture Act.

$4^{8} \S 3 \pi I(a)(\mathrm{r})$.

49 For a criticism of the rule see McLaughlin, Aspects of the Chandler Bill to Amend the Bankruptcy Act, 4 Univ. Chi. L. Rev. 369, 398 (I937). 
set off deposits made by an insolvent in the ordinary course of business within four months of bankruptcy even where the bank knows of the debtor's insolvency. ${ }^{\circ}$ This set-off rule will be important because the obligor-debtor will usually be a depositor of the trustee. Furthermore, because it will be difficult to show that a deposit by the obligor was made "out of the ordinary course of business," a "preference" obtained in avoidance of Section 3 II will not be easily set aside.

One of the exceptions which has been discussed frequently is that allowing the trustee to realize upon any property pledged simultaneously with any loan made within the "preference period," providing the trustee sustains the burden of proving it had no reasonable cause to believe a default under the indenture would occur within four months. ${ }^{5 x}$ Although this exception is intended to allow "rescue loans" to a limited extent, its critics assert that in effect such loans are prohibited because "rescue loans" are given under such circumstances that the lender cannot reasonably be sure the obligor will survive its financial difficulties. ${ }^{32}$ It is further pointed out that putting the burden of proof as to reasonable cause on the creditor is a harsh requirement and departs from the bankruptcy rule on this question. ${ }^{53}$ Moreover, the critics argue that when a "rescue loan" is needed the trustee is the only one concerned enough about the obligor to aid it. ${ }^{44}$ Thus, it has been suggested that the only requirement for a "rescue loan" be a making in "good faith." 55

The retention of the restriction on "rescue loans" nevertheless seems justifiable. The act only restricts, but does not bar completely, the giving of "rescue loans." And the trustee may, because of its position, have such knowledge of the financial circumstances of the obligor ${ }^{56}$ that it will not be unduly burdened in having to show reasonable cause.57 Admitting that the trustee is more helpful to the obligor in distress than another bank, without the requirement of showing lack of "reasonable cause to believe that a default would occur within four months" for a "rescue loan," a loan may be made simply to prolong the obligor's existence in order to avoid any sharing of recent large payments or collateral on loans. To lessen the requirement to "good faith," as suggested,

so New York County Nat'l Bank v. Massey, I92 U.S. I38 (Igo4); Gilbert's Collier, Bankruptcy II48 (Levi and Moore ed. I937).

sx $\& 3 \pi x(a)(C)$.

${ }^{52}$ S. Hearing on S. 477,76 th Cong., Ist Sess. 87,202 (I939); H.R. Hearing on H.R. $219 \mathrm{I}$ and H.R. 5220, 76th Cong., Ist Sess. 160 (1939).

53 S. Hearing on S. 477,76 th Cong., Ist Sess. 87 (1939). See 52 Stat. 869 (1938), II U.S.C.A. $\S 96 a, b$ (Supp. 1939).

54 H.R. Hearing on H.R. 219 I and H.R. 5220, 76 th Cong., Ist Sess. 308 (I939).

s5 S. Hearing on S. 2344, 75th Cong., Ist Sess. 147 (1937); H.R. Hearing on H.R. 219I and H.R. 5220, 76th Cong., Ist Sess. IO5 (I939).

${ }^{56}$ Posner, op. cit., supra note 32 , at 792.

57 See H.R. Hearing on H.R. 2191 and H.R. 5220, 76th Cong., Ist Sess. 268 (1939). 
would again allow loans where the trustee felt there was merely a possibility of success.

Another exception in the act allows a qualified indenture to exempt from the operation of the apportioning rule certain listed advances which preserve the trust property or remove prior liens..$^{8}$ This exemption, however, is permitted only where the notice provisions in the indenture concerning such advances have been followed. Coming within this category are such loans as those given to finance repairs for "preserving the property," to pay insurance premiums, to pay tax delinquencies, to pay rent defaults, and even to complete the building mortgaged.59 The policy in allowing a trustee to receive payments on such claims free of sharing seems defensible since these loans by definition benefit the bondholders, and further a priority will usually be given in bankruptcy. Nevertheless, in applying this exception, the courts should be careful not to extend it to include loans which arguably benefit the investor but clearly do not tend to have the effect of "preserving" the property subject to the lien of the indenture. Thus, no "preference" exemption should be given loans made to avoid an interest payment default which if it occurred would prevent the sale of unmarketed securities.60

Although the apportionment rule of the act confers no discretion on the commission, discretion is given to define "cash transaction" and "self-liquidating paper" as used in two of the exceptions. ${ }^{6 x}$ One exception permits a qualified indenture to exempt from the apportioning rule creditor relationships arising from what is essentially a "cash transaction" between the trustee and obligor, as, for example, where payment is by a check which may require a few days to clear; the other exception exempts from the apportioning formula credits arising from the acquisition of "self-liquidating paper" of the obligor, i.e., paper which will be paid from the proceeds of the transaction out of which it arose. ${ }^{62}$

\section{IV}

The draftsmen of Section 3 II have carefully attempted to prevent a circumvention of the section either by substituting collateral or by resignation. As a result, where the trustee-creditor is allowed to realize on collateral held, an attempt by the trustee to better secure himself by having the obligor substi-

${ }^{58} \S 3 \operatorname{II}(\mathrm{b})(2)$.

${ }^{59}$ Hallett v. Moore, 282 Mass. 380,185 N.E. 474 (1933); 2 Jones, Bonds and Securities $\S$ I042 (4th ed. 1935).

${ }^{60}$ Marshall \& Isley Bank v. Hackett, Hoff \& Thiermann, 213 Wis. 426, 434, 250 N.W. 866, 869 (1933); Coffey v. Lawman, 99 F. (2d) 245 (C.C.A. 6th r938); Connell v. City of Kaukauna, I64 Wis. 47r, 159 N.W. 927 (r917); First Trust Co. of Lincoln, Neb. v. Ricketts, 75 F. (2d) 309 (C.C.A. 8th I934). See also SEC, op. cit. supra note 4, pt. III, Committees for the Holders of Real Estate Bonds 22-9, 75-85 (x936).

${ }^{6 x} \S 3 \mathrm{I} 9(\mathrm{a})(2)$.

${ }^{62} \S 3 \times \mathrm{x}(\mathrm{b})(4)$, (6); Rules $\mathrm{T}-\mathrm{IIB}_{4}, \mathrm{~T}-\mathrm{IIB6}$. General Rules and Regulations under the Trust Indenture Act of 1939, at 9 (I940). 
tute more valuable property is provided against by limiting the trustee's realization on the latter collateral to the extent of the fair value of the original security ${ }^{63}$ Also, the trustee who resigns during the "preference period" is liable as though no resignation had occurred. ${ }^{64}$ Moreover, a trustee who resigns within four months of the "preference period" may not do what he otherwise would be unable to do had he continued as trustee-creditor. Thus, a trustee who has resigned is expressly brought within the "preferential collection" section, if the receipt of property or reduction of claim, for which it would have had to account had it remained as trustee, occurs within four months of default and within four months after resignation..$^{6}$

Also foreseen was the attempt to evade the section through an exception which permits the trust indenture to exempt from Section 3 II (a) a credit arising in favor of the trustee from disbursements as trustee or in any ministerial capacity in which it may serve the obligor ${ }^{66}$ Evasion is prevented by restricting the exemption to claims arising in "the ordinary course of business," thus excluding the trustee's lending to the obligor in the role of fiscal agent, in which capacity it could arguably claim exemption from Section 3 II(a).

In spite of the care taken, however, some of the exceptions may be interpreted to defeat the purpose of the section. The provision allowing the trustee to retain "the proceeds of the bona fide sale of any such claim by the trustee to a third person" is such an exception. ${ }^{67}$ Apparently the type of sale meant is one made without the intent to circumvent the purpose of the section. But a plausible argument could be made that "bona fide" refers only to the purchaser. If such a view is accepted the trustee bank can pass the claim on into the "regular flow" with the result that the purchaser may improve his creditor status without being subject to the indenture apportioning formula, and that the proceeds which the trustee receives from the sale are also exempt. Or, it may be argued that all that "bona fide" means is a "real" rather than "sham" sale. Under this last view even a collusive sale will be upheld.

The other exception which may afford a "loophole" is one which permits the exemption of a creditor relationship arising from ".... the ownership or acquisition of securities issued under any indenture, or any security or securities having a maturity of one year or more at the time of acquisition by the indenture trustee." 18 Although the suggestion that the period of maturity in the exception be reduced from a year to six months ${ }^{69}$ was apparently rejected to prevent a circumvention of the section by six-month lending, it was not pointed

$63 \S 3 \mathrm{II}(\mathrm{a})(\mathrm{D})$; cf. Richardson v. Union Mortgage Co., 2Io Iowa 346, 228 N.W. I03 (I929); Hazzard v. Chase Nat'l Bank of City of New York, I59 Misc. 57, 287 N.Y. Supp. 54 I (S. Ct. I936).

$64 \$ 3 \operatorname{II}(\mathrm{a})$. $65 \$ 3 \operatorname{II}(a)$.

$66 \S 3$ II(b)(3); S. Hearing on S. 2344, 75th Cong., Ist Sess. 6I (I937).

$67 \S 3$ II(a)(A)(ii).

$68 \& 3 \operatorname{II}(b)(x)$.

${ }^{69} \mathrm{~S}$. Hearing on S. 2344, 75th Cong., Ist Sess. 9I (I937). 
out that this provision sets up two classes of exemptions,,$^{70}$ namely: $x$ ) the ownership or acquisition of securities under any indenture, and 2) the ownership or acquisition of any security or securities having a maturity period of a year or more at the time of acquisition by the indenture trustee. As the terms "security" 7 and "indenture" 72 are defined in the act, the first class seems to exempt a creditor relationship arising from a trustee's giving an unsecured short-term loan in return for notes issued under an indenture. Moreover, by the same interpretation, the trustee may give a secured loan knowing the obligor will default within four months, providing the obligor follows the formality of issuing notes for the debt under a mortgage. To prevent circumvention of Section 3II through such interpretations of the above exceptions, it is submitted that such terms as "bona fide," "security," and "indenture," should have been more carefully defined by the act.

\section{MEASURE OF RECOVERY AGAINST A PROMOTER WHO SELLS PROPERTY TO A CORPORATION IN BREACH OF FIDUCIARY DUTY}

It is not uncommon for a promoter to profit by selling property to the corporation which he has organized. This profit may be made more or less secure through the adoption of various financing techniques whereby the sale is made at a time when the promoter and his affiliates are the sole shareholders. Inasmuch as all of the existing shareholders in the company may then be said to have consented to the profit with full knowledge, the company is bound and may not later rescind the sale or compel the promoter to disgorge his secret profits. ${ }^{x}$ In the absence of actionable deceit when these shares are later sold to the

${ }^{70}$ The analysis of the Trust Indenture Act made by the SEC in H.R. Rep. Ior6, 76th Cong., Ist Sess. at 49 (I939), does not contradict such an interpretation.

$7 \mathrm{~T}$ The definition of the Securities Act of 1933 is used by the Act, $\S 303(\mathrm{I})$.

Section 2(r) of the Securities Act defines "security" as "any note, stock, treasury stock, bond," etc., 48 Stat. 74 (1933), 15 U.S.C.A. § 77b (Supp. 1939).

72 "The term 'indenture' means any mortgage, deed of trust, trust or other indenture, . . . . under which securities are outstanding or are to be issued, whether or not any property, real or personal, is or is to be, pledged, mortgaged, assigned, or conveyed thereunder." $\$ 303(\mathrm{x})$.

I There is a conflict of authority as to whether an action will lie in favor of the company when there are later subscribers to new shares. One view, following Old Dominion Copper Mining \& Smelting Co. v. Lewisohn, 210 U.S. 206 (Ig08), holds that there is no corporate right of action even though, as part of the promotional scheme, these subscribers are contemplated. There may, however, be individual actions for fraud. Cf. McCandless v. Furlaud, 296 U.S. 140 (1935). The other view, following Old Dominion Copper Mining \& Smelting Co. v. Bigelow, 203 Mass. 159, 89 N.E. 193 (Igog), permits corporate action, holding that the fiduciary duty runs to the corporation as the promoters intended to make it. See CaliforniaCalaveras Mining Co. v. Walls, x70 Cal. 285, 149 Pac. 595 (rgr5); Hays v. The Georgian, 280 Mass. ro, I8r N.E. 765 (r932); In re British Seamless Paper Box Co., I7 Ch. D. 467 (I88r).

See generally, Ballantine, Corporations $\$ 49$ (I927); Stevens, Corporations I68 (I936); I Fletcher, Cyc. Corporations $\S$ I94 (perm. ed. I93I). 